\title{
Architectural longevity-in the case of the summer palace chandra-hauly in khiva city, Uzbekistan
}

\begin{abstract}
Hitherto, the knowledge of reconstruction of the .monuments, finishing layer should be a layer of cosmetics increase ventilation of deep understanding, even so, there have been just a common vision. The reason is traditional architectural secrets were lost and forgotten in today. One of them is a method of building construction's ventilation "khataba". Nevertheless, today majority considers reconstructing. Over the years for a number of methods are used for the medieval century architecture of buildings. Particularly, the foundation of the design of a tent yard restores from the wild reed as a waterproofing, cob walls and ventilation "khataba" method.

At the last decade, Central Asia had a various political and social views. The reason why, it has lost the shape of its traditional building style and national architecture ornaments, as well. According to the different causes, several tactics of a national construction have preserved by the architectural heritages. In the years of independence of Uzbekistan, the number of native researchers are looking for the forgiven architectural technics. This paper is also a piece of that kind of research articles.
\end{abstract}

Volume 2 Issue 5 - 2017

\section{Bonu Azizova}

Department of Landscape design, Tashkent Architecture and

Construction Institute, Uzbekistan

Correspondence: Bonu Azizova, Navoi Str I3, Landscape design department, Tashkent Architecture and Construction Institute, Uzbekistan, Tashkent, Uzbekistan, Email bonu.azizova@gmail.com

Received: March 24, 2017 | Published: May 12, 2017

Keywords: khiva city, khataba, ventilation, damp, reconstruction, preservation method, underground water, waterproofing

\section{Introduction}

2500-year old ancient city Khiva is located in the Southern-west part of Khorezm oasis. This beautiful city was a capital city of Khiva Khanate in the sixteenth century and the beginning of the twentieth century. Hitherto, the design and the principles of the architectural monuments of this city have not been fully researched. There is majority of intricate palace complexes in Khiva. One of that kind of palaces is the city palace of the yard. It has remained as the only multistorey cob-walled residential building at the territory of Central Asia. Chadra-hauli was built as a summer resident of the khan of Kiva in the XIV-XVIII centuries. This building is a four-storey building, which is situated near Ichan-Kala (Inner forest), was planned with the ancient traditional Char-bagh style on the edge of the pool.

Despite this architectural complex is on the World Heritage List of UNESCO, as well as, it attracts the attention of many tourists until today, it highly needs reconstruction and preservation (Figure 1). It is known that to increase the stability of buildings and structures is one of the main factors. Research shows that only strengthening the foundations of the building, construction and construction materials, measures to neutralise the effect of the mechanical force alone are not enough. The Earth's gravity, earthquakes, wind, snow, such as mechanical pressure, at the root of the plants that grow from the roof and walls around the monument and various rodents biological effects detrimental to the atmosphere during the precipitation as a result of the rise in the atmosphere and underground water and the effect of the permanent moisture the power to undermine is quite severe effect.

In recent years, scientific research to reconstructing building shows that used in architectural monuments of glazed tile and airframe segments soon (5-10 years) showed that spiralling spilt are today's biggest flaws. The reasons are ample. One of the most important cosmetic layers of salt in the groundwater and, through them is the negative impact of subversive. This, in turn, would undermine the very large amount of money loss and defection of the artistic architecture monuments in the country.

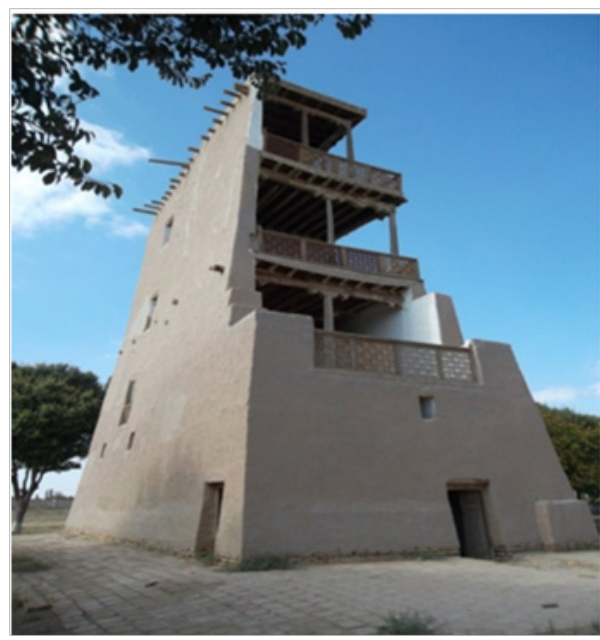

Figure I Chadra-hauli. Full view. Façade.

\section{Materials and methods}

Over the years for a number of methods are used for the medieval century architecture of buildings. Particularly, the foundation of the design of a tent yard restores from the wild reed as a waterproofing, ${ }^{2}$ cob walls and ventilation "khataba" method (Figure $2 \& 3$ ). Hitherto, the knowledge of reconstruction of the .monuments, finishing layer should be a layer of cosmetics increase ventilation of deep understanding, even so, there has been just a common vision. The reason is traditional architectural secrets were lost and forgotten in today. One of them is a method of building construction's ventilation "khataba". Nevertheless, today majority consider reconstructing. ${ }^{3-6}$ 
khataba" means just a blank (hollow space) between the layers of cosmetics with the construction of the building. In order to improve the quality of the repair is not enough. It is known by a few observations of the monument. Less known in science study works of authors such as Khumuliy, Rabbi Luria, Mutribiy, Abu Tokhirkho'ja in the medieval heritage monument observations of the theoretical basis of the method of "khataba" is rehabilitated. Now, its practical implementation is considered as the main ask.

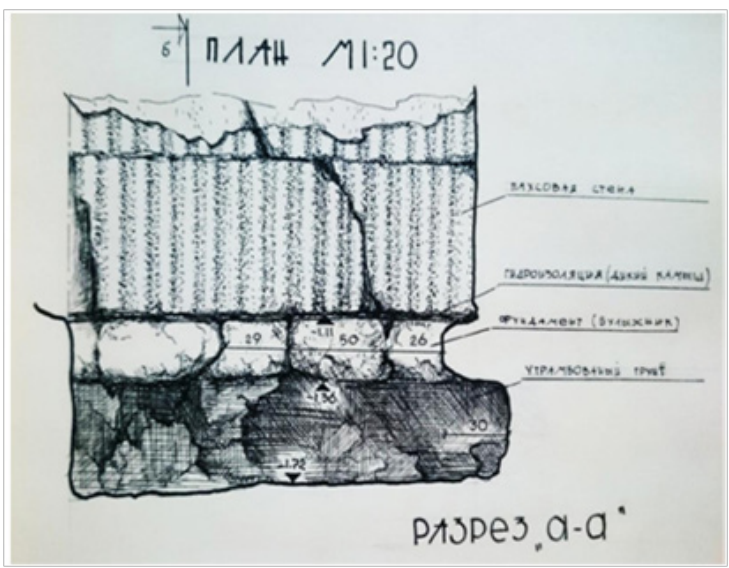

Figure 2 The section of the foundation of Chadra-hauli and hydroisolation and khataba method.

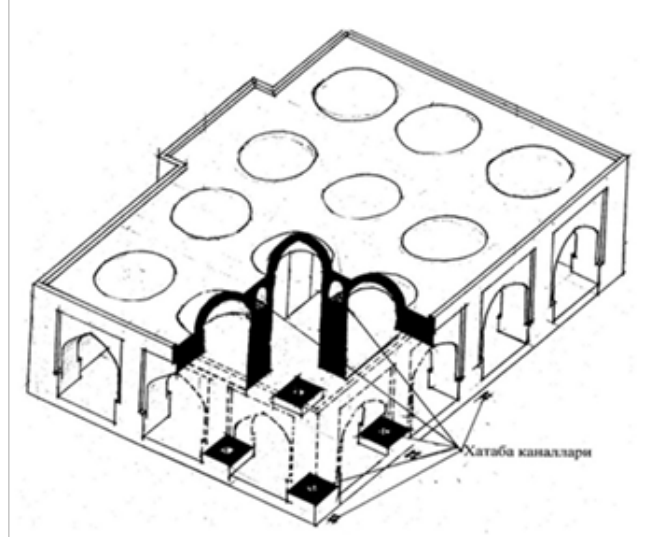

Figure 3 Samarkand. Example of khataba structure as in the medieval century mosque Imam al-Bukhari complex.

\section{Results and discussion}

To restore-down of buildings and erosion of damp constructions affect to collapsing down of cosmetic glazed surface layer (mask) of dome of the building. In order to eliminate of erosion is needed ventilation, for the construction of building and cosmetic layer, which affects through the atmosphere and underground water. Improving longevity of architectural monuments and their finishing layers "Khataba" techniques require to the implementation of the following tasks:

I. To determinate of khataba traces which preserved in the courtyard.

II. To restore the image of khataba graphics this was used in the yard.

III. To test a method khataba in the construction of building and cosmetic layer during the reconstruction process.
IV. To create a new mechanism of using khataba in other monuments.

Paying attention to the architectural monuments, a large layer part of the dome left frail and pale. As well as the medieval century architectural monuments' mosaic pattern can be seen to move. For example, Shokhi Zinda complex in Samarkand district reflux, feed my mother and the other domes of the mausoleums 193-1950- was restored, regardless of the make-up layer of the tire. The same situation is Mirzo Ulugbek Madrasah in Samarkand, it is repeatable repaired, so that significant layer of cosmetics has not been replaced. This is mainly because of the buildings themselves up to the underground water layer effects. It is remained by the majority of experts, however, solving measures have not decided at all, yet. There are a number of reasons. The most important reason is the former Soviet system of individual production in the $1920 \mathrm{~s}$, and crafts go to the fight against private property and the elimination of a large part of the home. Particularly, a number of architects, artists, and engineer masters have passed away. ${ }^{7-10}$

a. In cosmetic layers and distance of wall.

b. In the foundations of the building.

c. In the walls of the building.

d. In the roof and floor of the building.

e. In the building parts and a range of cosmetics.

At the dawn of its history, the humanity used natural construction materials, namely timber, natural stone, clay, straw, among which clay was the most widespread and easy one to use. Universally available and cheap, it was actively used in construction not only in Central Asia but also in many countries all over the world. Statistical data shows that about $30 \%$ of the world's population or around 1.5 million people live in clay houses. Around $20 \%$ of the above-mentioned population lives in cities and city suburbs. Central Asian rural areas have over $50 \%$ of housing and facilities built of natural clay. This is primarily caused by its availability, economic efficiency and excellent insulation qualities. ${ }^{11-13}$ First primitive rounded shape air bricks were first applied in Central Asia ten thousand years ago and are perpetually used since then. Some historical sites dated from early Middle Ages still are in more or less good condition. In the period preceding the spread of Islam in Central Asia, Termiz had numerous Buddha temples, stupas and castles, some of which survived till present time. Corner towers, some walls and arch covered corridors of Kirk-kyz palace in Termiz (10-11th century AD) maintained their original height, though its last clay dome collapsed in $1980 .{ }^{14}$

The most popular unburnt construction material was "pakhsa". It looked like a wall comprised of earthen belts of various height. Widely spread $75 \times 90 \times 100 \mathrm{~cm}$ (Ak-tepe castle) and $100 \times 90 \times 300 \mathrm{~cm}$ (Talibarzu castle) "pakhsa" blocks were manufactured directly on site. Air bricks, clay mortars, puddle and "guvalya" (rounded air bricks) were used as well. Clay has nothing harmful for human organism. Our granddads knew that. Thus, a medieval writer Narshakhi tells that Ismail, the governor of Bukhara, was advised to move from the City Palace built of burnt bricks to a clay countryside residence in the village of Zarmon.

The principal and probably the only drawback of clay construction materials is their poor earthquake resistance. Consequently, in middle ages, the clay, air brick and half-timber framed houses had no foundations but were erected on artificial puddle earth platforms. 
They served as damping anti-earthquake stabilisers to reduce the seismic waves.

\section{Conclusion}

Radical updating on methods of working out general plans of cities with unfairly enormous industrial-warehouse zones is required. It is necessary to introduce objects of small and average business, the idea of studying central city streets and introducing new types of building. Innovative ideas of architecture and urban-planning independence period should be deeply studied and introduced in curricula of the higher educational institutions of the Republic. Researches which were carried out in the years of 2007-2011 show that the method used since time immemorial architecture basis, and revealed of this information in written sources, and those information presents the importance of khataba in urban-planning.

The researchers describe that is a deepening of the urban history of urban studies proved that the application of theoretical knowledge comes from very ancient times. Briefly, the latest researches showed that we have had scientific innovation from the past which has not opened yet as khataba. To conclude with the traditional architecture of building constructions and damp depleting the protective "khataba" effective way to restore and application of modern architectural construction and a huge economic impact, architectural and archaeological monuments longevity. Nowadays, the surface of the dome is moving down in 2-3 years. Utilizing damp style khataba in buildings assists prolongs the life at least 100 years. Consequently, the economic efficiency could be increased to the amount of 30-50 times for each building to be compared to present situation.

\section{Acknowledgements}

None.

\section{Conflict of interest}

The author declares no conflict of interest.

\section{References}

1. Frederick Burnaby. A Ride to Khiva: Travels and Adventures in Central Asia Paperback. 2nd ed. Russia: Nabu Press; 1895. 398 p.

2. Christopher AA. A Carpet Ride to Khiva: Seven Years on the Silk Road Hardcover. 1st ed. UK: Icon Books Ltd; 2009. 334 p.

3. Philip Glazebrook. Journey to Khiva: A Writer's Search for Central Asia. USA: Kodansha Amer Inc; 1994. 228 p.

4. Ahmedov B. Tarixdan saвoqlar. 1st ed. Tashkent, Uzbekistan; 1994. 331 p.

5. Notkin ÎI. Khiva minarets. 1st ed. Tashkent, Uzbekistan; 1978. 328 p.

6. Mankovskaya LYu, Bulatova VA. Monuments of the architecture of Khorezm. Uzbekistan: Publishing House; 1978. 162 p.

7. Pugachenkova GA, Rempel LI. Outstanding monuments of architecture of Uzbekistan. Tashkent, Uzbekistan; 1975.

8. Bulatov MS. Geometric harmonization in the architecture of Central Asia IX-XV centuries. USA: GRVL; 1988. $321 \mathrm{p}$.

9. Field JV. The invention of infinity: Mathematics and art in the Renaissance. USA: Oxford University Press; 1997. 384 p.

10. Ifrah G. The Universal History of Numbers: From Prehistory to the Invention of the Computer. Questia trusted online research. 1998.

11. Radelet-de PG, Benvenuto E. Entre mécanique et architecture. 1995:8788.

12. Sarton G. Hellenistic science and culture in the last three centuries B.C. Dover. 1993.

13. Afanasev KN. Ancient metrology and architecture (Russian), Istor-Astronom. Issled; 1998. p. 194-201.

14. Ahmedov MK. Methodological Bases of Reconstruction cities in Uzbekistan." Samarkand conference. HiCECA: Planning and Networking for Historical Cities in Eastern and Central Asia, gathers with the core members from Japan, China, Korea, Uzbekistan, Azerbaijan, Russia for a better conservation, regeneration and planning of historical cities in Eurasia. 